\title{
Pupils' Perceptions of Attainment in Music at the Start of Secondary School in England: A Descriptive Analysis
}

\author{
Dimitra Kokotsaki \\ Correspondence: Dimitra Kokotsaki, School of Education, University of Durham, Leazes Road, DH1 1TA, Durham, \\ UK.
}

Received: January 5, 2017

doi:10.11114/jets.v5i5.2353
Accepted: April 8, $2017 \quad$ Online Published: April 14, 2017

URL: https://doi.org/10.11114/jets.v5i5.2353

\begin{abstract}
The provision of constructive feedback gives meaning to educational assessment and is an important requirement in every good educational system. In addition to the value of summative and formative judgements about a learner's progress, when pupils are given opportunities to assess their own work, they can develop a sense of ownership and responsibility towards their work that can help promote a proactive and critical learning attitude. The present study aims to explore the issue of self-assessment in music learning and to contribute to the discussion about the importance of pupils' involvement in evaluating their musical skills. It particularly looks at pupils' views on their musical progress during their first year in secondary school $(\mathrm{N}=530)$. The findings suggest that equal attention needs to be given to pupils' development in all areas of musical achievement. Furthermore, pupils' sense of musical progress seems to be related to their overall enjoyment of music.
\end{abstract}

Keywords: music education, music assessment, self-assessment, attitudes to music

\section{Introduction}

The assessment of pupils' educational outcomes is an important part of any educational system because it can provide both summative information to demonstrate the extent to which pupils have achieved and improved or failed to show adequate progress, but also to evidence areas in students' learning that can show improvement if appropriate interventions and support are put into place. Summative judgements about learning are common practice in all levels of educational practice and have the potential to positively contribute to students' learning when they are taken seriously in conjunction with formative practices as a means to actively help improve learning (Brookhart, 2001; Black, Harrison, Hodgen, Marshall \& Serret, 2011).

Meaningful educational assessment should involve the learner both in a reactive way to formative feedback provided by the teacher but also in a self-reflective process of evaluating one's own sense of competence, skill development and current achievements. Self-assessment has been widely used in education and has been found to contribute to enhanced student learning and improved behaviour (Boud, 2003; Ross, 2006). Scott (2012) has used the term 'assessment as learning' to refer to students' self-reflection and monitoring of their own learning in music education. Its primary purpose, Scott argues, is to help students learn and encourage them to 'continually strive to perform at more sophisticated levels' (2012, p.33).

When students receive appropriate guidance and training as to how to assess their work, they can develop a sense of ownership and responsibility towards their work that can help promote a proactive and more critical learning attitude. The learner in this case will be more receptive to the teacher's feedback as an active and dynamic process of critical reflection will take place where the learner compares their own evaluative judgements with those of the teacher. This will allow the development of fertile ground in the learner's mind which will be conducive to better learning and enhance understanding, a key element for achievement (McDonald, 2007).

\section{Theoretical Framework for the Study}

Even though music teaching and learning are often perceived as difficult to assess, clearly defining the attributes that characterise what is to be measured can demystify the perceived complexity of assessing music learning. Well-defined learning targets can provide the teacher and the student with common understanding about what is to be learnt and can simplify the assessment of this learning (Asmus, 1999). When students are involved in discussions about the exact nature of learning outcomes and about ways in which these can be assessed, a classroom environment is created imbued 
by notions of critical pedagogy where students act as 'amateur music critics' (Abrahams, 2005). In this environment, students' informed opinions can act as a significant source of a healthy exchange of ideas, active and purposeful learning. In response to pupil feedback, the teacher may take 'constructive action' by adjusting his/her classroom strategies to offer more support according to pupils' needs (Shuler, 2011).

Student self-assessment has been explored in a range of educational phases and subjects, such as in the context of learning English as a foreign language (Butler \& Lee, 2010), in science (White \& Frederiksen, 1998), in maths (Ross, Hogaboam-Gray \& Rolheiser, 2002), in writing (Ross, Rolheiser \& Hogaboam-Gray, 1999) and in higher education (Falchikov \& Boud, 1989; Lindblom-ylänne, Pihlajamäki \& Kotkas, 2006). In music, research on self-assessment has been carried out in the context of musical performance, primarily in higher education, where it has been found to be a valuable tool (see, for example, Daniel, 2001). However, the use of self-assessment as a tool to explore students' perceptions of their own learning in music is lacking in music education research.

The present study aims to address this gap in the literature. It seeks to explore the issue of self-assessment in music learning and to contribute to the discussion about the importance of pupils' involvement in evaluating their musical skills and competences. It particularly aims to answer the following research question:

How do pupils perceive their musical progress in the areas of composing, reviewing and evaluating, performing and listening during their first year in secondary school?

This paper forms part of a larger study that investigated pupils' attitudes and their perceptions of attainment in music (Kokotsaki, 2015; Kokotsaki, 2016; Kokotsaki, 2017).

\section{Method}

Data about pupils' attitudes to music and their perceived attainment were collected during the two phases of the project (Phase I: May 2011 - July 2012 \& Phase II: July 2012 - July 2013). The findings regarding pupils' attitudes have been published elsewhere (Kokotsaki, 2016; Kokotsaki, 2017). This paper reports on self-attainment data collected by pupils at the end of their first year in secondary school (Year 7) during the first phase of the project who were attending six different secondary schools at the North East of England. There were 530 pupils overall that completed a self-assessment rating scale at the end of Year 7 (School 1: N=67, School 2: N=20, School 3: N=41, School 4: N=112, School 5: N=41, School 6: N=249). The six schools were selected to represent geographical and socio-economic diversity within the north east of England (for more information regarding the selection of the schools, see Kokotsaki, 2015).

The self-assessment rating scale was developed on the basis of the attainment levels that described the level of progress that pupils attending state schools were expected to make under the statutory guidance of the old version of the National Curriculum for Music. The scale was developed purposefully in order to capture pupils' self-attainment judgments in all aspects of the four areas of performing, composing, listening, reviewing and evaluating for Levels 3 and 4 in line with these attainment levels, and compare and contrast their responses. Therefore, the questionnaire items aimed to capture all of the relevant skills in detail. The inclusion of all these required skills was expected to produce a detailed account of pupils' perceptions in these areas. As each component of the attainment levels was represented by a relevant question that addressed a particular skill, we can be reasonably confident that the scale is strong in content coverage (Streiner \& Norman, 2008). As the content of the scale is tightly linked to the assessment criteria, we can make the assumption that the results of the study will 'allow us to draw the inferences about the people that we wish to make' (Steiner \& Norman, 2008 , p.252), i.e. capturing a detailed picture of pupils' perceptions of their musical skills.

The statutory guidance of the old version of the National Curriculum for Music was in operation until October 2013 when the new National Curriculum was published (DfE, 2013). This new document describes the music content that pupils in all the Key Stages should be taught but does not contain any specific information about attainment levels expected to be achieved at particular time points. Since this piece of work was carried out during the time when the previous version was the statutory document for music, the specified attainment level descriptors were used to devise a self-rating scale appropriate for the age of pupils that was being investigated. According to the previous guidance, the range of levels within which the great majority of pupils were expected to work was between levels 2 and 5 for pupils at the end of Key Stage $2^{1}$, and between levels 3 and 7 for pupils at the end of Key Stage 3. Consequently, pupils would be expected to be working at levels 3 and 4 during the two years (Years 6 and 7) of their transition to secondary school (for

\footnotetext{
${ }^{1}$ Key Stage 2 covers the four years of schooling in maintained schools in England and Wales normally known as Year 3, Year 4, Year 5 and Year 6, when pupils are aged between 7 and 11. Key Stage 3 refers to the lower years of secondary school in England and Wales normally known as Year 7, Year 8 and Year 9, when pupils are aged between 11 and 14.
} 
a description of levels 3 and 4 under the old statutory guidance, see Appendix II).

Pupils were asked to indicate their agreement on a 3 point rating scale (1: I can do this well, 2: I can do this some of the time, 3: I can't do this yet) to a number of statements. The rating scale consisted of 54 items which covered skills in composing, reviewing and evaluating, performing and listening. There were 24 statements covering skills at level 3 and 30 statements at level 4 At level 3, there were 8 statements for composing, 5 statements for reviewing and evaluating, 7 statements for performing and 4 for listening. The level 4 scale contained 10 statements for composing, 5 statements for reviewing and evaluating, 10 statements for performing and 5 for listening (see Appendix I). Pupils completed the rating scale at the end of Year 6 and at the end of Year 7. The Cronbach's alpha reliability coefficient for the overall self-assessment rating scale is 0.98 which indicates a very high level of reliability (see, for example, Cortina, 1993). The reliability coefficient was also very high for the Level 3 scale $(\alpha=0.94)$, the Level 4 scale $(\alpha=0.97)$ and for the different areas of composing (Level 3 composing: $\alpha=0.83$; Level 4 composing: $\alpha=0.9$ ), performing (Level 3 performing: $\alpha=0.9$; Level 4 performing: $\alpha=0.94$ ), listening (Level 3 listening: $\alpha=0.84$; Level 4 listening: $\alpha=0.9$ ) and reviewing and evaluating (Level 3 reviewing and evaluating: $\alpha=0.82$; Level 4 reviewing and evaluating: $\alpha=0.9$ ). In the analysis, a comparison is made between pupils' perceived musical ability at the end of Year 7 and their attitudes to music. The overall scale on attitudes to music comprises two sub-scales of liking music and making music. These have been presented and analysed in Kokotsaki $(2015,2016)$ and are presented in Table 8.

Even though this analysis is based on pupil self-attainment data at the end of Year 7, a comparison has also been made between Year 6 and Year 7 using a matched sample of 121 pupils (the same pupils completed the self-assessment rating scale at the end of Year 6 and at the end of Year 7). It was observed that at the end of the first year in secondary schools, pupils felt more comfortable with rating their musical skills in the four different areas whereas, at the end of primary school, completing the questionnaire was seen as a more difficult and troublesome process. Pupils had varying musical experiences in the different feeder primary schools that they attended with some having rich musical experiences and others much narrower and limited. The first year in secondary school provided much more systematic and organised musical training for all (Kokotsaki, 2015) which had helped pupils become more confident and aware of their musical development.

\subsection{Ethical Considerations}

Participants' anonymity has been preserved in the presentation of the findings. The study has adhered to all ethical obligations as suggested by Rubin and Rubin (1995). It was also in accordance with the ethical requirements of the University and was approved by the School of Education's Ethics Committee. The Committee issued certification that the research met acceptable ethical standards following an ethical approval application which also contained a detailed description of the study methods and reporting strategies. Permission to access the school to collect data from the project was also gained by the head teacher of each school who had previously agreed for their school to take part in the research.

\section{Findings}

Perceived achievement increased at the end of Year 7 and a statistically significant difference was found in pupils' responses about their perceived ability from the end of Year 6 to the end of Year 7 in all four areas of composing, reviewing, performing and listening in both Levels 3 and 4 (Table 1).

Please insert Table 1 somewhere here.

Table 2 (in Appendix I) presents the means and standard deviations for all 54 questionnaire items ${ }^{2}$. Mean values ranged from 2.49 for questionnaire item 3 (When improvising, I keep to a basic pulse: Composing Level 3) to 1.76 for questionnaire item 51 (When describing the music I hear, I can identify and explain musical devices such as pedal, riff, ostinato and loop: Listening Level 4).

At the end of Year 7, composing was perceived as being the strongest area of musical achievement at level 3 followed by reviewing with performing and listening coming next (Figure 1). At level 4, reviewing was the strongest area followed by composing, performing and listening. In both levels, composing and reviewing were perceived as being the strongest areas of musical achievement with performing and listening being the weakest.

\section{Please insert Figure 1 somewhere here.}

The next step in the analysis involved examining the areas where pupils felt most and least competent in music at the end of Year 7 by looking at which 10 questionnaire items had the highest and the lowest means. As shown in Tables 3 and 4, 9 out of the 10 items with the highest means were relevant to composing and reviewing (for Composing: 5 items

\footnotetext{
${ }^{2}$ Please note that the data values were reversed in the analysing of the rating scale so that the highest score of 3 would represent higher pupil confidence.
} 
at Level 3 and 2 items at Level 4 and for Reviewing: 1 item at Level 3 and 1 item at Level 4). Regarding the 10 items with the lowest means, all were relevant to performing and listening (for Performing: 1 item at Level 3 and 5 items at Level 4 and for Listening: 4 items at Level 4).

Pupils felt more competent in repeating and building on patterns already heard and in keeping to a basic pulse when improvising, in repeating their ideas, in combining more than one musical idea and in choosing different sounds that fitted well with each other when developing their ideas and combining layers of sound. They also felt able to decide how their own work did what they were asked to do, to choose higher pitches for melodies and lower pitches for bass lines, they were aware of the combined effect of all the parts playing together and they could describe what the composer or performer intended when reviewing their performances and compositions.

They felt less able to pitch notes accurately or to take the upper or lower part of a 2-part piece when singing, to maintain their own part in performance with awareness, confidence and accuracy, to make rhythmic sense of simple notations or to identify and use suitable musical terms and musical devices to describe the music they hear and in making comparisons between pieces in different styles.

\section{Please insert Tables 3 \& 4 somewhere here.}

Table 5 presents the percentages of pupils answering 3 ('I can do this well'), 2 ('I can do this some of the time') or 1 ('I can't do this yet') to the 10 items with the highest means and the 10 items with the lowest means as presented in Tables 3 and 4 and discussed above. These three possible responses represent three categories of pupil competence, those pupils of low competence (answered 1), those pupils of medium competence (answered 2) and those pupils of high competence (answered 3). Looking at the items with the highest means, the responses of the highly competent pupils ranged from $37.7 \%$ of pupils feeling able to keep to a basic pulse when improvising ( $42.6 \%$ felt that they could not do this yet), to $26.1 \%$ of pupils being able to choose higher pitches for melodies and lower pitches for bass lines to combine sounds (50.8\% felt that they could not do this yet).

Regarding the items with the lowest means, responses ranged from $20.7 \%$ ('I am aware of how my part fits with the others') to $11.1 \%$ ('I can identify and explain musical devices, such as pedal, riff, ostinato and loop') for the highly competent pupils. For those pupils that perceived themselves as being of low competence, responses ranged from $61.9 \%$ regarding their ability to identify and explain musical devices to $53.6 \%$ regarding pupils' level of awareness when performing with others. In all of the 10 items with the lowest means, one fifth of pupils or fewer were of high competence and more than half perceived themselves as being of low competence.

Please insert Table 5 somewhere here.

A comparison was made between pupils' attitudes to music (for the two sub-scales of liking music and making music that make up the overall scale, see Table 8) and their perceived musical ability at the end of Year 7 (Table 6). Small but significant correlations were found for the overall Attitudes to Music scale and the two subscales of Liking Music and Making Music and most of the areas of pupils' musical involvement. Correlations were slightly higher for the Liking Music scale compared to the Making Music scale, especially for the areas of performing (level 3), listening (level 3), composing (level 4) and performing (Level 4). Levels of significance ranged from .134 $(\mathrm{p}<.05)$ in the area of reviewing at level 3 to $.221(\mathrm{p}<.01)$ in the area of listening at level 3 regarding pupils' overall attitudes to music.

\section{Please insert Table 6 somewhere here.}

A final analysis was carried out to compare self-perceived achievement for instrumentalists and non-instrumentalists. As Table 7 shows, pupils that played a musical instrument were more confident in music at the end of Year 7 with a significant difference found in all areas of composing, reviewing, performing and listening in both levels 3 and 4 .

\section{Please insert Table 7 somewhere here.}

\section{Discussion}

The Music programmes of study for Key Stage 3 in England (Years 7-9, 11-14 years of age) emphasise the importance for all children between the ages of 11 and 14 to participate in a music education of high quality where, through learning to sing and perform, compose, listen to, review and evaluate music, they make musical progress and develop a love for music (DfE, National Curriculum in England, 2013). The findings of the present study indicate that pupils do not feel that they make equivalent progress in these four areas of musical achievement with performing and listening to music lagging behind the areas of composing and reviewing. Reasons behind this limited self-perceived competence in listening and performing cannot be identified in this study but it can be speculated that the four areas of musical achievement may not be given equal attention in the six schools that participated in the study. Pupils might be given more opportunities to make up their own music and evaluate this and the music of others but might have fewer chances to engage in performing, singing and listening activities. Listening, in particular, can sometimes be viewed with 
scepticism by teachers, as, even though they might believe that careful listening is important, they might neglect focusing on 'deep-listening experiences' and regard it instead as a 'passive process' (Campbell, 2005, p.30). As a result, these pupils felt less able to identify a range of musical elements and devices to provide descriptions of musical and expressive effects. Likewise, in performing and singing, they seemed to lack confidence in making use of simple notations, to play music with others, to pitch notes accurately when singing, to identify phrasing differences or sing a 2-part piece confidently with others.

It could be argued that these skills could be developed further in the second and third year of Key Stage 3 (Years 8 and 9). However, it is worrying that pupils at the end of their first year in secondary school expressed lack of confidence in these areas. If these skills are lacking at this stage in pupils' musical education, then their musical progression defined as increased musical understanding influenced by prior knowledge and understanding of all aspects of music in an interrelated way (Todd, 2012) might suffer in the following two years of lower secondary school (Key Stage 3). This could have repercussions on pupils' option choices at GCSE (General Certificate of Secondary Education ${ }^{3}$ ) level where music has been one of the subjects with the lowest uptake (Lamont \& Maton, 2008). If, as Little (2009) argues, pupils may not choose to study music as a subject at GCSE level when they do not perceive it as a career option, effective music provision at the very beginning of secondary school becomes even more important as, beyond these first three years in secondary school, the majority of pupils would not have the opportunity to make any further advancement in their musical knowledge and skills. Some pupils' limited musical education would then have a negative knock-on effect on their lifelong learning and engagement with music. Pitts (2011), for example, found that secondary school performing opportunities and singing within a secondary school choir were the most influential educational experiences for the adults in her study who had maintained a lifelong interest in music. The present study has explored, however, the views of a limited number of pupils at the North East of England and the findings cannot be generalised more broadly. Exploring pupils' perceptions of their attainment in music in future research using a larger sample of participants in a variety of educational settings will help provide a more in depth understanding of their views in different contexts.

Pupil self-assessment provides a measure of self-efficacy which is considered in the literature as a strong predictor of subsequent achievement (see, for instance, Pajares and Kranzler, 1995, for mathematics achievement and McPherson and McCormick, 2006, for achievement in musical performance). Jinks and Lorsback (2003), for example, regard self-efficacy as 'antecedent to academic success because it motivates behaviour and leads to success' (p. 113). Pupils' ability to reflect on their own achievements and musical progress can show evidence of high or low self-efficacy beliefs and this can be a powerful indicator to the teacher of possible changes that need to be made to the curriculum so that pupils' learning can improve in certain areas. Adjusting the teaching content according to pupils' perceptions of their musical competence, can create a more learner-centred environment where learners are mindfully engaged and are active contributors to the nature of their musical experience enabling 'learner ownership of the musical process and product' (Blair, 2009, p.42). This context can be perceived as one in which Habermas' notion of 'deliberative democracy', where children participate in decision making in the classroom through the expression of mutual respect and 'communicative action', can find fertile ground (Dann, 2016).

The self-assessment rating scale used in this study shows promise as a self-reflection and evaluation tool that pupils can use in the music classroom. It worked better for the pupils attending secondary school (Year 7 pupils) who were now receiving systematic music provision whereas there was big variability in provision in the primary schools attended by the pupils in the study. The rating scale had very high reliability and we can recommend it for classroom use, in its current form or adapted to be aligned to specific learning objectives. Perhaps not surprisingly, the children in this study who played a musical instrument rated their musical skills more highly than the non-musicians in all areas of composing, reviewing, performing and listening at both levels. This indicates a higher sense of competence for those pupils who had some prior experience in playing musical instruments.

Furthermore, considering that a small but significant correlation was found between self-perceived ability and attitudes to music (particularly regarding liking music) in the areas of composing, performing and listening, the possible relationship between feeling good about one's musical ability and musical attitudes becomes an area worth exploring. In other words, if pupils feel competent in music at school, they might enjoy music more which would then lead to a greater willingness to work harder and even better musical progress. A high sense of competence would be the stimulus for a cyclical process of effort, progress, further enjoyment and desire to improve more. This possible relationship between sense of competence and enjoyment of school music coupled with the musicians' higher levels of confidence as found in the study, suggests that early childhood opportunities to engage with learning musical instruments may be crucial for children's subsequent musical development in the secondary school. Future research should explore this possible link between self-perceived ability and attitudes to music more extensively with a bigger sample of pupils.

\footnotetext{
${ }^{3}$ General Certificate of Secondary Education: a public examination in specified subjects for 16-year-old schoolchildren.
} 


\section{References}

Abrahams, F. (2005). Transforming classroom music instruction with ideas from critical pedagogy. Music Educators Journal, 92(1), 62-67. https://doi.org/10.2307/3400229

Asmus, E. P. (1999). Music assessment concepts. Music Educators Journal, 86(2), 19-24. https://doi.org/10.2307/3399585

Black, P., Harrison, C., Hodgen, J., Marshall, B., \& Serret, N. (2011). Can teachers' summative assessments produce dependable results and also enhance classroom learning? Assessment in Education. Principles, Policy \& Practice, 18(4), 451-469. https://doi.org/10.1080/0969594X.2011.557020

Blair, D. (2009). Stepping aside: Teaching in a student-centred music classroom. Music Educators Journal, 95(3), $42-45$. https://doi.org/10.1177/0027432108330760

Boud, D. (2003). Enhancing learning through self assessment. London and New York: RoutledgeFalmer.

Brookhart, S. M. (2001). Successful students' formative and summative uses of assessment information. Assessment in Education: Principles, Policy \& Practice, 8(2), 153-169. https://doi.org/10.1080/09695940123775

Butler, Y. G., \& Lee, J. (2010). The effects of self-assessment among young learners of English. Language Testing, 27(1), 5-31. https://doi.org/10.1177/0265532209346370

Campbell, P. S. (2005). Deep listening to the musical world. Music Educators Journal, 92(1), 30-36. https://doi.org/10.2307/3400224

Cortina, J. M. (1993). What is coefficient alpha? An examination of theory and applications, Journal of Applied Psychology, 78(1), 98-104. https://doi.org/10.1037/0021-9010.78.1.98

Daniel, R. (2001). Self-assessment in performance. British Journal of Music Education, 18(3), 215-226. https://doi.org/10.1017/S0265051701000316

Dann, R. (2016). Developing understanding of pupil feedback using Habermas' notion of communicative action. Assessment in Education: Principles, Policy \& Practice, 23(3), 396-414. https://doi.org/10.1080/0969594X.2015.1056083

DfE (2013). National Curriculum in England: Music Programmes of Study. Department for Education: London.

Falchikov, N., \& Boud, D. (1989). Student self-assessment in higher education: a meta-analysis. Review of Educational Research, 59(4), 395-430. https://doi.org/10.3102/00346543059004395

Jinks, J., \& Lorsbach, A. (2003). Introduction: motivation and self-efficacy belief. Reading and Writing Quarterly, 19, 113-118.Kokotsaki, D. (2015). Improving the primary-secondary transition in music education. Nuffield Foundation, London. https://doi.org/10.1080/10573560308218

Kokotsaki, D. (2016). Pupils' attitudes to school and music at the start of secondary school. Educational Studies, 42(2), 201-220. https://doi.org/10.1080/03055698.2016.1160822

Kokotsaki, D. (2017). Pupil voice and attitudes to music during the transition to secondary school. British Journal of Music Education, 34(1), 5-39. https://doi.org/10.1017/S0265051716000279

Lamont, A., \& Maton, K. (2008). Choosing music: exploratory studies into the low uptake of music GCSE. British Journal of Music Education, 25(3), 267-282. https://doi.org/10.1017/S0265051708008103

Lindblom-ylänne, S., Pihlajamäki, H., \& Kotkas, T. (2006). Self-, peer- and teacher-assessment of student essays. Active Learning in Higher Education, 7(1), 51-62. https://doi.org/10.1177/1469787406061148

Little, F. L. (2009). An exploration into the uptake rates of GCSE music with a focus on the purposes of music in school. Unpublished PhD thesis. School of Education, University of Durham, UK.

McDonald, B. (2007). Self assessment for understanding. The Journal of Education, 188(1), 25-40.

McPherson, G. E., \& McCormick, J. (2006). Self-efficacy and music performance. Psychology of Music, 34(3), 322-336. https://doi.org/10.1177/0305735606064841

Pajares, F., \& Kranzler, J. (1995). Self-efficacy beliefs and general mental ability in mathematical problem-solving. Contemporary Educational Psychology, 20(4), 426-443. https://doi.org/10.1006/ceps.1995.1029

Pitts, S. (2009). Roots and routes in adult musical participation: investigating the impact of home and school on lifelong musical interest and involvement. British Journal of Music Education, 26(3), 241-256. https://doi.org/10.1017/S0265051709990088 
Ross, J. A. (2006). The reliability, validity, and utility of self-assessment. Practical Assessment, Research, and Evaluation, 11(10), 1-13.

Ross, J. A., Hogaboam-Gray, A., \& Rolheiser, C. (2002). Student self-evaluation in grade 5-6 mathematics: Effects on $\begin{array}{lllll}\text { problem-solving } & \text { achievement. }\end{array}$ https://doi.org/10.1207/S15326977EA0801_03

Ross, J. A., Rolheiser, C., \& Hogaboam-Gray, A. (1999). Effects of self-evaluation training on narrative writing. Assessing Writing, 6(1), 107-132. https://doi.org/10.1016/S1075-2935(99)00003-3

Rubin, H. J., \& Rubin, I. S. (1995). Qualitative interviewing: the art of the hearing data. Thousand Oaks: Sage.

Scott, S. J. (2012). Rethinking the roles of assessment in music education. Music Educators Journal, 98(3), 31-35. https://doi.org/10.1177/0027432111434742

Shuler, S. C. (2011). Music education for life: Music assessment, part 1: what and why. Music Educators Journal, 98(2), 10-13. https://doi.org/10.1177/0027432111427651

Streiner, D. L., \& Norman, G. R. (2008). Health measurement scales: A practical guide to their development and use. Oxford \& New York: Oxford University Press. https://doi.org/10.1093/acprof:oso/9780199231881.001.0001

Todd, J. S. (2012). Musical progression in the English primary school: What is it, what does it look like and how do teachers realise it? Unpublished doctoral dissertation. School of Education, University of Durham, UK.

White, B. Y., \& Frederiksen, J. R. (1998). Inquiry, modeling, and metacognition: Making science accessible to all students. Cognition and Instruction, 16(1), 1133-118. https://doi.org/10.1207/s1532690xci1601_2

\section{Appendix I}

Table 1. Changes in pupils' perceived ability from the end of Year 6 to the end of Year 7

\begin{tabular}{llllll}
\hline & End of Y6 & End of Y7 & Number of pupils & Wilk's Lambda & Partial Eta Squared \\
\hline Composing Level 3 & 18.21 & $19.06(\mathrm{p}<.05)$ & 119 & .957 & .043 \\
Reviewing Level 3 & 10.31 & $11.36(\mathrm{p}<01)$ & 119 & .895 & .105 \\
Performing Level 3 & 14.31 & $15.86(\mathrm{p}<.01)$ & 112 & .914 & .086 \\
Listening Level 3 & 8.11 & $8.99(\mathrm{p}<.01)$ & 115 & .923 & .077 \\
Composing Level 4 & 17.50 & $22.53(\mathrm{p}<.01)$ & 107 & .798 & .202 \\
Reviewing Level 4 & 8.45 & $11.78(\mathrm{p}<.01)$ & 109 & .731 & .269 \\
Performing Level 4 & 16.13 & $21.44(\mathrm{p}<.01)$ & 102 & .784 & .216 \\
Listening Level 4 & 7.8 & $10.57(\mathrm{p}<.01)$ & 108 & .781 & .219 \\
\hline
\end{tabular}

Table 2. Self-assessment rating scale at the end of Year 7 (Means and Standard Deviations)

\begin{tabular}{|c|c|c|c|c|c|}
\hline & & & & \multicolumn{2}{|c|}{ End of Y7 } \\
\hline & & & & mean & s.d. \\
\hline & \multirow{3}{*}{$\begin{array}{l}\text { Improvising } \\
\text { melodic and } \\
\text { rhythmic phrases }\end{array}$} & \multirow[t]{3}{*}{ When improvising } & 1.I use a limited range of rhythms and note values & 2.30 & .636 \\
\hline & & & 2. I repeat and build on patterns already heard & 2.42 & .726 \\
\hline & & & 3. I keep to a basic pulse & 2.49 & .715 \\
\hline & \multirow[t]{3}{*}{ Developing ideas } & \multirow{3}{*}{$\begin{array}{l}\text { When changing and } \\
\text { extending ideas }\end{array}$} & 4. I repeat my ideas & 2.48 & .642 \\
\hline Composing & & & 5. I use big contrasts of pitch, tempo and dynamics & 2.13 & .712 \\
\hline \multirow[t]{4}{*}{ Level 3} & & & 6. I combine more than one musical idea & 2.33 & .763 \\
\hline & \multirow{6}{*}{$\begin{array}{l}\text { Combining layers } \\
\text { of sound } \\
\text { Suggesting } \\
\text { improvements }\end{array}$} & \multirow[t]{2}{*}{ To combine sounds, } & 7. I select several layers, including rhythms, melody and & 2.22 & .716 \\
\hline & & & 8. I choose different sounds that fit well with each other & 2.43 & .714 \\
\hline & & \multirow{4}{*}{$\begin{array}{l}\text { When looking back } \\
\text { at our performances } \\
\text { and compositions }\end{array}$} & 9. I can decide how my own work does what I was asked & 2.44 & .720 \\
\hline \multirow{3}{*}{$\begin{array}{l}\text { Reviewing } \\
\text { and } \\
\text { Evaluating }\end{array}$} & & & 10. I can comment on the different musical elements used & 2.28 & .751 \\
\hline & & & 11. I can describe the effect that was intended and how my & 2.14 & .740 \\
\hline & & & own and other people's work reflects this & & \\
\hline \multirow[t]{4}{*}{ Level 3} & Commenting on & When reviewing & 12. I can recognise and describe how musical elements have & 2.22 & .748 \\
\hline & how intentions & performances and & been combined & & \\
\hline & have been achieved & compositions & 13. I can describe what the composer or performer intended & 2.17 & .764 \\
\hline & Singing & When singing & 14. I sing in tune & 2.30 & .823 \\
\hline \multicolumn{2}{|l|}{ Performing } & & 15. I sing with expression & 2.07 & .820 \\
\hline \multirow[t]{6}{*}{ Level 3} & \multirow{5}{*}{$\begin{array}{l}\text { Performing on an } \\
\text { instrument } \\
\text { Performing on my } \\
\text { own or with others }\end{array}$} & When performing & 16. I can perform simple parts by ear & 2.25 & .837 \\
\hline & & & 17. I read simple rhythms and tunes from notation & 2.28 & .849 \\
\hline & & $\begin{array}{l}\text { When taking an } \\
\text { individual part }\end{array}$ & $\begin{array}{l}\text { 18. I perform rhythmically simple parts that use only a few } \\
\text { notes }\end{array}$ & 2.39 & .822 \\
\hline & & & 19. I play in time, keeping a steady pulse & 2.11 & .815 \\
\hline & & $\begin{array}{l}\text { When performing } \\
\text { with others }\end{array}$ & 20. I am aware of how my part fits with the others & 2.02 & .862 \\
\hline & Describing & When listening to & 21. I use suitable musical words to describe how elements & 2.13 & .851 \\
\hline
\end{tabular}




\begin{tabular}{|c|c|c|c|c|c|}
\hline & \multirow[t]{3}{*}{ comparing } & \multirow[t]{3}{*}{ music } & \multicolumn{3}{|l|}{ such as tempo and dynamics are used and combined } \\
\hline & & & 22. I compare the ways in which the music creates a feeling & 2.04 & .852 \\
\hline & & & 23. I can explain what I like and dislike about the music I & & \\
\hline Listening & & & hear & 2.12 & .843 \\
\hline \multirow[t]{3}{*}{ Level 3} & Evaluating & $\begin{array}{l}\text { When thinking } \\
\text { about the music I } \\
\text { have heard }\end{array}$ & $\begin{array}{l}\text { 24. I can recognise how different musical elements, e.g. } \\
\text { tempo and dynamics, are combined and used to create } \\
\text { different moods and feelings }\end{array}$ & 2.29 & .849 \\
\hline & Improvising & When improvising & 25 . I use a suitable range of pitches & 2.27 & .844 \\
\hline & melodic & & 26. I show a sense of shape, combining steps and leaps & 2.08 & .859 \\
\hline \multirow{9}{*}{$\begin{array}{l}\text { Composing } \\
\text { Level } 4\end{array}$} & rhythmic phrases & & 27. I follow and develop set patterns & 2.16 & .849 \\
\hline & & & 28. I am aware of the pulse and beat & 2.09 & .803 \\
\hline & Developing ideas & When changing and & 29. I use repeated patterns & 2.05 & .897 \\
\hline & & extending ideas & 30. I use simple variation techniques & 2.05 & .899 \\
\hline & & & $\begin{array}{l}\text { 31. I use contrasts of one or more musical element (e.g. } \\
\text { pitch, dynamics, tempo and timbre) }\end{array}$ & 2.20 & .873 \\
\hline & Combining layers & To combine sounds & 32. I create melody and harmony parts & 2.13 & .867 \\
\hline & of sound & & $\begin{array}{l}\text { 33. I choose higher pitches for melodies, lower pitches for } \\
\text { bass lines, etc. }\end{array}$ & 2.35 & .837 \\
\hline & & & $\begin{array}{l}\text { 34. I am aware of the combined effect of all the parts } \\
\text { playing together }\end{array}$ & 2.33 & .964 \\
\hline & $\begin{array}{l}\text { Suggesting } \\
\text { improvements }\end{array}$ & $\begin{array}{l}\text { Thinking about our } \\
\text { performances and }\end{array}$ & $\begin{array}{l}\text { 35. I can describe how my own and other people's work } \\
\text { matches what we were asked to do }\end{array}$ & 2.32 & .836 \\
\hline \multirow{6}{*}{$\begin{array}{l}\text { Reviewing } \\
\text { and } \\
\text { Evaluating } \\
\text { Level } 4\end{array}$} & & compositions & $\begin{array}{l}\text { 36. I can compare my own work with that of others, } \\
\text { describing differences and similarities }\end{array}$ & 2.16 & .835 \\
\hline & & & $\begin{array}{l}\text { 37. I can give constructive suggestions for next steps and } \\
\text { improvements, using appropriate musical terms }\end{array}$ & 2.22 & .832 \\
\hline & Commenting on & When reviewing & 38. I can describe what the composer or performer intended & 2.38 & .834 \\
\hline & $\begin{array}{l}\text { how intentions } \\
\text { have been achieved }\end{array}$ & $\begin{array}{l}\text { performances and } \\
\text { compositions }\end{array}$ & $\begin{array}{l}\text { 39. I can use suitable musical terms to explain how well the } \\
\text { composer or performer met these intentions }\end{array}$ & 2.15 & .846 \\
\hline & Singing & When singing & 40. I pitch notes accurately & 1.98 & .903 \\
\hline & & & 41. I can tell the difference between similar-sounding & 2.01 & .923 \\
\hline \multirow{9}{*}{$\begin{array}{l}\text { Performing } \\
\text { Level } 4\end{array}$} & & & 42. I sing with others, taking the upper or lower part of a & 1.94 & .963 \\
\hline & & & 2-part piece & & \\
\hline & $\begin{array}{l}\text { Performing on an } \\
\text { instrument }\end{array}$ & When performing & $\begin{array}{l}\text { 43. I copy simple patterns by ear, repeating phrases } \\
\text { accurately after a few hearings }\end{array}$ & 2.12 & .898 \\
\hline & & & $\begin{array}{l}\text { 44. I can play three or more phrases in a row, having learned } \\
\text { them separately }\end{array}$ & 2.09 & .880 \\
\hline & & & $\begin{array}{l}\text { 45. I make rhythmic sense of simple notations, including } \\
\text { staff notation and grid notation }\end{array}$ & 1.85 & .866 \\
\hline & $\begin{array}{l}\text { Performing on my } \\
\text { own or with others }\end{array}$ & $\begin{array}{l}\text { When taking an } \\
\text { individual part }\end{array}$ & $\begin{array}{l}\text { 46. following rehearsal, I can maintain own part in } \\
\text { performance with confidence and accuracy }\end{array}$ & 2.02 & .893 \\
\hline & & & 47. I maintain a reliable sense of pulse & 2.05 & .892 \\
\hline & & $\begin{array}{l}\text { When performing } \\
\text { with others }\end{array}$ & $\begin{array}{l}\text { 48. I fit my part with other different parts, aware of how the } \\
\text { different parts fit together }\end{array}$ & 2.09 & .913 \\
\hline & & & 49. I perform with mostly accurate timing and pulse & 2.14 & .916 \\
\hline \multirow[t]{5}{*}{$\begin{array}{l}\text { Listening } \\
\text { Level } 4\end{array}$} & $\begin{array}{l}\text { Describing } \\
\text { comparing }\end{array}$ & $\begin{array}{l}\text { When describing } \\
\text { the music I hear }\end{array}$ & $\begin{array}{l}\text { 50. I use suitable musical terms to describe tempo, } \\
\text { dynamics, pitch and structure }\end{array}$ & 1.97 & .913 \\
\hline & & & $\begin{array}{l}\text { 51.I can identify and explain musical devices such as pedal, } \\
\text { riff, ostinato and loop }\end{array}$ & 1.76 & .875 \\
\hline & & & $\begin{array}{l}\text { 52. I can make comparisons between pieces in different } \\
\text { styles }\end{array}$ & 2.01 & .914 \\
\hline & & & 53. I can give my opinion and justify my preference & 2.07 & .928 \\
\hline & Evaluating & $\begin{array}{l}\text { When thinking } \\
\text { about the music I } \\
\text { have heard }\end{array}$ & $\begin{array}{l}\text { 54. I use suitable musical terms to explain how different } \\
\text { musical elements and devices are used to create expressive } \\
\text { effects }\end{array}$ & 1.99 & .889 \\
\hline
\end{tabular}

\section{Appendix II}

\section{Level 3:}

Pupils recognise and explore the ways sounds can be combined and used expressively. They sing in tune with expression and perform simple melodic and rhythmic parts. They improvise repeated patterns and combine several layers of sound with an awareness of the combined effect. They recognise how the different musical elements are combined and used expressively and make improvements to their own work, commenting on the intended effect.

\section{Level 4:}

Pupils identify and explore the relationship between sounds and how music reflects different intentions. While 
performing by ear and from notations, they maintain their own part with awareness of how the different parts fit together and the need to achieve an overall effect. They improvise melodic and rhythmic phrases as part of a group performance and compose by developing ideas within musical structures. They describe, compare and evaluate different kinds of music using an appropriate musical vocabulary. They suggest improvements to their own and others' work, commenting on how intentions have been achieved.

Table 3. The 10 Items with the Highest Means

\begin{tabular}{|c|c|c|}
\hline $\begin{array}{l}\text { Musical } \\
\text { Activity/Level }\end{array}$ & Scale Item & Mean \\
\hline Composing Level 3 & 2. When improvising - I repeat and build on patterns already heard. & 2.42 \\
\hline Composing Level 3 & 3. When improvising - I keep to a basic pulse. & 2.49 \\
\hline Composing Level 3 & 4. When changing and extending ideas - I repeat my ideas. & 2.48 \\
\hline Composing Level 3 & 6. When changing and extending ideas - I combine more than one musical idea. & 2.33 \\
\hline Composing Level 3 & 8. To combine sounds - I choose different sounds that fit well with each other. & 2.43 \\
\hline Reviewing Level 3 & $\begin{array}{l}\text { 9. When looking back at our performances and compositions - I can decide how } \\
\text { my own work does what I was asked. }\end{array}$ & 2.44 \\
\hline Performing Level 3 & $\begin{array}{l}\text { 18. When taking an individual part - I perform rhythmically simple parts that use } \\
\text { only a few notes. }\end{array}$ & 2.39 \\
\hline Composing Level 4 & $\begin{array}{l}\text { 33. To combine sounds - I choose higher pitches for melodies, lower pitches for } \\
\text { bass lines etc. }\end{array}$ & 2.35 \\
\hline Composing Level 4 & $\begin{array}{l}\text { 34. To combine sounds - I am aware of the combined effect of all the parts } \\
\text { playing together. }\end{array}$ & 2.33 \\
\hline Reviewing Level 4 & $\begin{array}{l}\text { 38. When reviewing performances and compositions - I can describe what the } \\
\text { composer or performer intended. }\end{array}$ & 2.38 \\
\hline \multicolumn{3}{|c|}{ Table 4. The 10 Items with the Lowest Means } \\
\hline $\begin{array}{l}\text { Musical } \\
\text { Activity/Level }\end{array}$ & Scale Item & Mean \\
\hline Performing Level & 20. When performing with others - I am aware of how my part fits with the others. & 2.02 \\
\hline Performing Level & 40. When singing - I pitch notes accurately. & 1.98 \\
\hline Performing Level & 41. When singing - I can tell the difference between similar-sounding phrases. & 2.01 \\
\hline Performing Level & $\begin{array}{l}\text { 42. When singing - I sing with others, taking the upper or lower part of a 2-part } \\
\text { piece. }\end{array}$ & 1.94 \\
\hline Performing Level & $\begin{array}{l}\text { 45. When performing - I make rhythmic sense of simple notations, including staff } \\
\text { notation and grid notation. }\end{array}$ & 1.85 \\
\hline${ }_{4}$ Performing Level & $\begin{array}{l}\text { 46. When taking an individual part - following rehearsal, I can maintain own part in } \\
\text { performance with confidence and accuracy. }\end{array}$ & 2.02 \\
\hline Listening Level 4 & $\begin{array}{l}\text { 50. When describing the music I hear - I use suitable musical terms to describe } \\
\text { tempo, dynamics, pitch and structure. }\end{array}$ & 1.97 \\
\hline Listening Level 4 & $\begin{array}{l}\text { 51. When describing the music I hear - I can identify and explain musical devices, } \\
\text { such as pedal, riff, ostinato and loop. }\end{array}$ & 1.76 \\
\hline Listening Level 4 & $\begin{array}{l}\text { 52. When describing the music I hear - I can make comparisons between pieces in } \\
\text { different styles. }\end{array}$ & 2.01 \\
\hline Listening Level 4 & $\begin{array}{l}\text { 54. When thinking about the music I have heard - I use suitable musical terms to } \\
\text { explain how different musical elements and devices are used to create expressive } \\
\text { effects. }\end{array}$ & 1.99 \\
\hline
\end{tabular}

Table 5. Pupils of high/medium/low competence for the items with the highest and the lowest means

\begin{tabular}{llll}
\hline Scale Items & Low & Medium & High \\
& Competence & Competence
\end{tabular}


Items with the lowest means

20. When performing with others - I am aware of how my part fits with the others.

40. When singing - I pitch notes accurately.

41. When singing - I can tell the difference between similar-sounding phrases.

42. When singing - I sing with others, taking the upper or lower part of a 2-part piece.

45. When performing - I make rhythmic sense of simple notations, including staff notation and grid notation.

46. When taking an individual part - following rehearsal, I can maintain own part in performance with confidence and accuracy.

50. When describing the music I hear - I use suitable musical terms to describe tempo, dynamics, pitch and structure.

51. When describing the music I hear - I can identify and explain musical devices, such as pedal, riff, ostinato and loop.

52. When describing the music I hear - I can make comparisons between pieces in different styles.

54. When thinking about the music I have heard - I use suitable musical terms to explain how different musical elements and devices are used to create expressive effects.

Items with the highest means

2. When improvising - I repeat and build on patterns already heard.

3. When improvising - I keep to a basic pulse.

4. When changing and extending ideas - I repeat my ideas.

6 . When changing and extending ideas - I combine more than one musical idea.

8. To combine sounds - I choose different sounds that fit well with each other.

9. When looking back at our performances and compositions - I can decide how my own work does what I was asked.

18. When taking an individual part - I perform rhythmically simple parts that use only a few notes.

33. To combine sounds - I choose higher pitches for melodies, lower pitches for bass lines etc.

34. To combine sounds - I am aware of the combined effect of all the parts playing together.

38. When reviewing performances and compositions - I can describe what the composer or performer intended.

Table 6. Comparison between pupils' attitudes to music and their self-assessed musical ability (*significant at $\mathrm{p}<.05,{ }^{* *}$ significant at $\mathrm{p}<.01)$

\begin{tabular}{llll}
\hline End of Year 7 & & & \\
\hline & Attitudes to Music & Liking Music & Making Music \\
Composing Level 3 & .095 & .102 & .060 \\
Reviewing Level 3 & $.134^{*}$ & $.130^{*}$ & .091 \\
Performing Level 3 & $.200^{* *}$ & $.224^{* *}$ & $.136^{*}$ \\
Listening Level 3 & $.221^{* *}$ & $.215^{* *}$ & $.186^{* *}$ \\
Composing Level 4 & $.205^{* *}$ & $.237^{* *}$ & $.148^{* *}$ \\
Reviewing Level 4 & $.143^{*}$ & $.143^{*}$ & $.117^{*}$ \\
Performing Level 4 & $.209^{* *}$ & $.235^{* *}$ & $.159^{* *}$ \\
Listening Level 4 & $.165^{* *}$ & $.182^{* *}$ & $.113^{*}$ \\
\hline
\end{tabular}

\section{Percentage responses}

$53.6 \quad 25.7$

$56.5 \quad 24.5$

55.8

60.7

59.2

54.1

56.2

24

18.8

28.8

27.1

25.9

27

25.6

27

17.6

43.6

42.6

40.6

45.4

43.6

44.2

46.4

50.8

48.5

23.7

$\begin{array}{ll}22.3 & 34.1 \\ 19.7 & 37.7\end{array}$

$25.2 \quad 33.9$

$24.2 \quad 30.4$

$23-33.4$

$20 \quad 33.6$

$23.1 \quad 26.1$

27.8

19.1

32.2
$21.7 \quad 34.1$

Table 7. Self-perceived achievement for instrumentalists and non-instrumentalists

\begin{tabular}{|c|c|c|c|c|c|c|}
\hline \multirow{4}{*}{$\begin{array}{l}\text { Composing Level } \\
3 \\
\text { Reviewing Level } 3\end{array}$} & \multicolumn{2}{|c|}{ Non-instrumentalist } & \multicolumn{4}{|c|}{ Instrumentalist } \\
\hline & $\begin{array}{l}\text { Mean } \\
(N=324)\end{array}$ & $\begin{array}{l}\text { Std. } \\
\text { Deviation }\end{array}$ & $\begin{array}{l}\text { Mean } \\
(N=41)\end{array}$ & $\begin{array}{l}\text { Std. } \\
\text { Deviation }\end{array}$ & $t(d f)$ & $\begin{array}{l}\text { Sig. } \\
\text { (2-tailed) }\end{array}$ \\
\hline & 18.45 & 3.68 & 21.28 & 4.1 & $\begin{array}{l}-4.463 \\
(351)\end{array}$ & $\mathrm{p}=0$ \\
\hline & 11.03 & 2.88 & 12.72 & 2.76 & $\begin{array}{l}-3.498 \\
(347)\end{array}$ & $\mathrm{p}=0$ \\
\hline Performing Level & 15.09 & 4.8 & 18.12 & 3.54 & $\begin{array}{l}-4.846 \\
(335)\end{array}$ & $\mathrm{p}=0$ \\
\hline Listening Level 3 & 8.4 & 2.8 & 10 & 2.3 & $\begin{array}{l}-3.478 \\
(342)\end{array}$ & $\mathrm{p}=0$ \\
\hline $\begin{array}{l}\text { Composing Level } \\
4\end{array}$ & 20.98 & 6.22 & 24.87 & 5.33 & $\begin{array}{l}-3.800 \\
(323)\end{array}$ & $\mathrm{p}=0$ \\
\hline Reviewing Level 4 & 10.87 & 3.57 & 13.41 & 2.62 & $\begin{array}{l}-5.387 \\
(324)\end{array}$ & $\mathrm{p}=0$ \\
\hline $\begin{array}{l}\text { Performing Level } \\
4\end{array}$ & 19.67 & 7.71 & 24.72 & 5.5 & $\begin{array}{l}-3.858 \\
(321)\end{array}$ & $\mathrm{p}=0$ \\
\hline Listening Level 4 & 9.49 & 3.9 & 12.3 & 2.98 & $\begin{array}{l}-4.320 \\
(325)\end{array}$ & $\mathrm{p}=0$ \\
\hline
\end{tabular}

Table 8. The two sub-scales of Liking Music and Making Music that make up the Attitudes to Music scale 


Corrected
$\begin{aligned} & \text { Item-Total } \\ & \text { Correlation }\end{aligned}$

\section{Copyrights}

Copyright for this article is retained by the author(s), with first publication rights granted to the journal.

This is an open-access article distributed under the terms and conditions of the Creative Commons Attribution license which permits unrestricted use, distribution, and reproduction in any medium, provided the original work is properly cited. 